\title{
The Effect of Brand Credibility, Brand Image and Customer Satisfaction on Behavioural Intentions in
} Traditional Medicine Market

\author{
Peter Kwasi Oppong \\ Cape Coast Technical University, Cape Coast, Ghana \\ peteroppong72@gmail.com
}

\begin{abstract}
Brands with stronger image, credibility, and greater customer satisfaction engender favourable behavioural intentions, which serves as an essential competitive weapon in a market. The impact of brand image, credibility, and satisfaction on behavioural intentions are well-documented in the literature. There is, however, little or no research on the influence of credibility and image on behavioural intentions through the intervening role of satisfaction in the traditional medicine market. As a result, the research aimed to assess the intervening role of customer satisfaction in the effect of brand image and credibility on behavioural intentions in the traditional medicine market. Data were distributed to a sample of 265 customers via a systematic sampling strategy. The hypotheses formulated were tested by using covariance-based structural equation modelling. The research confirmed that satisfaction perfectly mediated the effect of credibility on customers' behavioural intentions in the traditional medicine market. However, no mediational relationship between the brand image and behavioural intentions was established. Consequently, this study contributes to the brand theory by displaying the mediated role of customer satisfaction in the impact of brand credibility on the customers' behavioural intentions, particularly in the traditional medicine market. As an emerging industry, this paper also advances the practitioners' knowledge about how to build and manage credibility, satisfaction, and image to strengthen the customers' behavioural intentions in the traditional medicine market.
\end{abstract}

Keywords: Brand credibility, Brand image, Customer satisfaction, Behavioural intentions, Herbal medicine.

\section{Introduction}

The significance of plant medicines in health care delivery has attracted much attention across the globe in the last few decades. Herbal medicines include processed or raw plant materials and herbal medicinal products with curative or human benefits obtained from plants (WHO, 2007). A study reported that nearly 70 to $80 \%$ of the population in the advanced world have consumed herbal medicine on one occasion in their lifetime (WHO, 2008), whilst approximately 70 to $95 \%$ of people dwelling in the less developed economies still use herbal medicines for primary health care (WHO, 2011). Furthermore, about $80 \%$ of Ghanaians continue to rely on plant medicines to meet their health needs (UNDP, 2007). To meet the growing demand for plant medicinal products in the Cape Coast metropolis, the herbal medicine manufacturers, particularly those operating on a relatively large scale, have adopted various product and process innovations. The product innovations involved the production of assorted products like pills, tablets, capsules, creams in tubes and mixtures bottled to increase their lifespan while adopting modern marketing practices for distribution. While the process innovations have also led to the adoption of diverse modern manufacturing equipment such as tube-filling for packaging creams, machines for bottling liquid preparations with complete seals, semi-automated capsule-filling machines for capsules, and labelling machines (Essegbey, Awuni, Essegbey, Akuffobea \& Mica, 2014).

The Food and Drugs Authority (FDA) and the Traditional Medicine Practice Council (TMPC) oversee the manufacturing and distribution of plant medicines in the Cape Coast metropolis. The pharmacies, over-thecounter medicine stores, herbal stores and herbal clinics are the recognised retail outlets for distributing herbal medicinal products as non-prescription medicines in the Cape Coast metropolis (WHO, 2011; Essegbey et al., 2014). Competition in the traditional medicine (TM) market in Cape Coast is growing partly due to the influx of complementary and alternative medicines (CAM) and conventional drugs (Essegbey et al., 2014), leading to lower prices and ultimately, lower industry`s profits. It has been asserted that brands with favourable credibility, image, and greater customer satisfaction generate positive behavioural intentions in the market (Ali, Omar \& Amin, 2013; Lee, Hsu, Han \& Kim, 2010; Cronin, Brady \& Hutt, 2000). Favourable behavioural intentions are manifested in the consumers' preference of a company over others, repeated purchases, increase quantity of purchases, word-of-mouth recommendations, and willingness to pay price 
premium (Zeithaml, Berry \& Parasuraman, 1996; Rambocas, Kirpalani \& Simms, 2018; Buil, Martinez \& de Chernatony, 2013; Saha \& Theingi, 2009). This may lead to the growth and survival of TM firms in the Cape Coast metropolis.

The importance of brand credibility, image and satisfaction to behavioural intentions is well-documented in the literature (Ryu, Lee \& Kim, 2012; Cronin et al., 2000; Lee et al., 2010; Ali et al., 2013). However, there is little or no research on the mediated role of satisfaction in the effect of image and credibility on behavioural intentions, particularly in the TM market in the Cape Coast metropolis. Consequently, this paper seeks to evaluate customer satisfaction's intervening role in the path between credibility, image and behavioural intentions in the Cape Coast TM market. As a result, this paper extends the brand theory by displaying the impact of brand credibility and image on the customers' behavioural intentions via the intervening role of satisfaction in the TM market in the Cape Coast metropolis. Besides, as an emerging industry, this study equips the practitioners' knowledge about how to successfully build and sustain brand credibility, satisfaction and image to strengthen the customers' behavioural intentions in the TM market.

\section{Literature Review and Research Hypotheses}

Behavioural Intentions: Customer behavioural intentions have received considerable attention from academia and practitioners in recent years because they are regarded as critical indicators of a company's survival in a keen competitive environment. Behavioural intentions are signs which show whether a firm 's clients will stay or desert to a rival firm and its market offerings (Zeithaml et al., 1996). The authors further stated that customers who exhibit positive behavioural intentions build bonds with the firm and unfavourable behavioural intentions defect. Extant literature shows that favourable behavioural intention is demonstrated in preference of a company over others, repeated purchases, increase in the volume of purchases, word-of-mouth behaviour, and desire to pay price premium (Zeithaml et al., 1996; Rambocas et al., 2018; Buil et al., 2013; Saha \& Theingi, 2009).

Zeithaml et al. (1996) emphasised that favourable behavioural intentions positively impact the firm`s profitability as the longevity of customers` relationship with a firm reduces marketing cost, increases wordof-mouth, purchases volume and ability to charge high prices. In contrast, unfavourable behavioural intentions negatively affect the firm's financial position in terms of loss of the customer, decrease in purchases, and an increase in the cost of attracting new ones. A review of the literature shows that some researchers have studied behavioural intentions as a single construct (Ali et al., 2013; Ryu et al., 2012; Cronin et al., 2000; Lee et al., 2010). However, other authors have examined behavioural intentions by considering each specific aspect (Zeithaml et al., 1996; Rambocas et al., 2018; Buil et al., 2013; Saha \& Theingi, 2009). In this research, however, behavioural intentions will be analysed as a unidimensional construct comprising word-of-mouth, repeated purchases, and desire to pay price premium consistent with earlier authors' work (Ali et al., 2013; Ryu et al., 2012; Cronin et al., 2000).

Brand Credibility: Brand credibility is acknowledged as one of the critical factors that ease brand selection since it removes the likely perceived risk of purchasing decision process. Brand credibility refers to the believability of the brand`s information, which allows customers to recognise that the brand has the capacity and ability to continuously serve its intended purpose (Erdem \& Swait, 2004). According to the authors, brand credibility consists of trustworthiness and expertise. The brand`s trustworthiness shows the extent to which consumers perceived the brand's willingness to deliver its stated purpose. In contrast, the expertise indicates the brand`s capability to fulfil its intended purpose. Keller (2013), however, proposed that brand credibility relates to the customers' perception of the authenticity of the brand. The author further argued that brand credibility entails expertise, trustworthiness and attractiveness. The expertise concerns the brand`s competence, innovativeness, and leadership in the market. In contrast, trustworthiness shows how reliable the brand is and holds the customer`s interest at heart.

Lastly, attractiveness looks at the brand ability to create fun and pleasure, and whether is worth buying. The trustworthiness and expertise indicate the total outcome of past and present marketing campaigns (Erdem \& Swait, 2004). It has been emphasised that incomplete and lop-sided market information causes customers to question products' overall excellence, resulting in greater perceived purchase and consumption risks. 
However, a credible brand has the potential to minimise the product search cost and perceived risk, while enriching the products' overall excellence, which can create confidence in the product claims of the company (Erdem \& Swait, 1998). It has also been confirmed that credible brands potentially enhance customer satisfaction (Othman, Kamarohim \& Nizam, 2017; Ameri \& Behnam, 2014), and behavioural intentions in the market (Ali et al., 2013; Ryu et al., 2012). Consequently, the following hypotheses are postulated:

H1: Brand credibility is significantly and directly related to customer satisfaction

H2: Brand credibility is significantly and directly related to behavioural intentions

Brand Image: Brand image has been well-recognised as a core brand asset that provides value for a company and its clients in the market (Keller, 2013). According to Keller (1993), the brand image indicates the perceptions consumers hold about a brand and is manifested in the associations stored in consumers' mind. Brand association is anything a customer connects to a brand (Aaker, 1991), which conveys meaning to him (Keller, 1993). The brand association exists in many forms but may relate to a product's attributes or characteristics unrelated to it. However, an association may consist of brand attributes or benefits. Brand attributes are those descriptive attributes that define an offering, whilst the benefit reflects the value assigned to the product's features (Keller, 2013). A favourable and unique brand association is a source of differentiation, extensions, a basis for buying decisions, processing, generating product information, and stimulating positive attitudes and feelings toward a brand (Aaker, 1991). The author further noted that brand image provides the basis for purchase decision and a source of customer satisfaction. The brand image also significantly influences customers` behavioural intentions (Lee et al., 2010; Ali et al., 2013) and satisfaction (Izzudin \& Novandarii, 2018; Yulianti \& Tung, 2013). Hence, the following hypotheses are posited:

H3: Brand image is significantly and directly related to behavioural intentions

H4: Brand image is significantly and directly related to customer satisfaction

Customer Satisfaction: Customer satisfaction plays an essential role in a business's success because it serves as a root for retaining profitable customers. Customer satisfaction measures the degree to which a product meets or exceeds customer expectations (Ferrell \& Hartline, 2011; Lovelock \& Witz, 2016). Zeithaml, Bitner and Gremler (2018) also stated that satisfaction is the assessment of a product by the consumer as to whether that product has fulfilled the needs and desires of the customer. Moreover, Kotler and Keller (2012) defined satisfaction as the feelings of pleasure or dissatisfaction of a customer that emerge from comparing the perceived performance of the product to expectations. Studies on customer satisfaction are anchored on the expectancy-disconfirmation model, which indicates that confirmation and disconfirmation of preconsumption expectations is the basis for determining satisfaction. Consumers experience the product's perceived performance during and after consumption and compare it to their expectations. Satisfaction judgements are then made by comparing the product's perceived performance and prior expectations (Lovelock \& Witz, 2016). If the perceived performance is lower than expectations, it is referred to as negative disconfirmation. On the other hand, if perceived performance is higher than expectations, positive disconfirmation occurs, and if it matches expectations, confirmation also occurs.

In other words, the customer is equally dissatisfied, satisfied and delighted if the perceived performance falls short, matches and exceeds expectations respectively. Customer's form expectations from their prior purchase experiences, friends` and associate's advice, marketers and competitors`activities (Kotler \& Keller, 2012). Highly delighted customers generally stay loyal, are more likely to engage in repeated purchases, advocate for a firm and its products, purchase more, less responsive to price increases and likely to switch to competitors (Kotler \& Keller, 2012; Ferrell \& Hartline, 2011). Prior studies also pointed out that customer satisfaction contributes to increasing favourable behavioural intentions (Rambocas et al., 2018; Cronin et al., 2000; Ryu et al., 2012). Similarly, satisfaction is directly influenced by credibility (Othman et al., 2017; Ameri \& Behnam, 2014) and image (Aaker, 1991), and in turn, satisfaction significantly enhances behavioural intentions (Cronin et al., 2000; Ryu et al., 2012). Consequently, the following hypotheses are stated:

H5: Customer satisfaction is significantly and directly related to behavioural intentions

H6: Customer satisfaction mediates the relationship between brand credibility and behavioural intentions

H7: Customer satisfaction mediates the relationship between brand image and behavioural intentions

Research Conceptual Framework: The conceptual model explains graphically or narratively the essential variables used and their inter-relationships in research (Miles, Huberman \& Saldăna, 2014). In this research, 
credibility and image are independent variables, and satisfaction is a mediating variable, whereas behavioural intention is a dependent variable. The conceptual framework depicted in Figure 1 indicates that brand credibility and image directly influence satisfaction, which directly impacts behavioural intentions. Moreover, credibility and satisfaction have a direct effect on behavioural intentions. Here, credibility is measured as the authenticity of the brand`s information, requiring that the brand continuously deliver its promise (Erdem \& Swait, 2004). The brand image also looks at consumers ' perceptions about a brand and is demonstrated in the associations registered in the consumer's mind (Keller, 1993). Likewise, behavioural intention measures the extent to which customers will stay with or defect from a supplier and its offerings (Zeithaml et al., 1996). Customer satisfaction is also operationalised as customer's feelings of satisfaction or dissatisfaction from contrasting the product's perceived performance to expectations (Kotler \& Keller, 2012).

Figure 1: The Conceptual Model

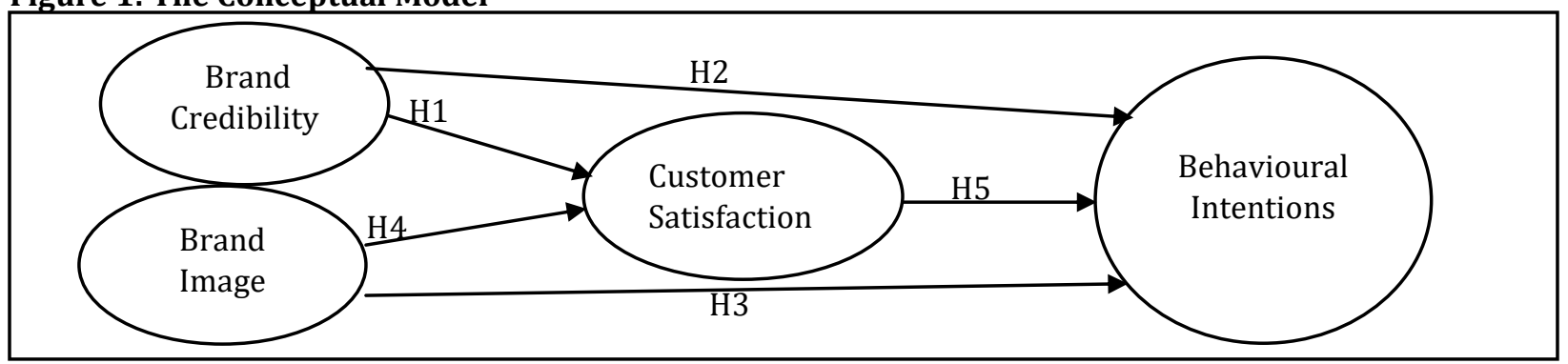

Source: Developed by the Researcher

\section{Research Methodology}

The methodology employed to evaluate the hypothesised relationship stated to address the study's purpose is spelt out below.

Population and Sampling Techniques: The research population consists of locally-manufactured herbal medicines approved by the GFDA and 26 herbal retail outlets found in the central business district in Cape Coast. The herbal stores were chosen because they are mandated to sell only herbal medicines. The study`s population also comprises 854 customers above 18 years who buy herbal medicines for their consumption from these stores in the Metropolis. The number of the herbal retail outlets was sourced from TMPC in Cape Coast, while that of the customers was from the herbal retail stores' daily sales. Following Krejcie and Morgan's (1970) model for computing sample size, 265 customers participated in this study. The respondents were recruited through systematic sampling. This approach allows the researcher to pick respondents without prior information about the sampling frame`s elements (Malhotra, Nunan \& Birks, 2017).

Scale Items Development and Data Collection Procedure: The customers` perceptions of brand credibility, image, satisfaction, and behavioural intentions were obtained from a five-point survey questionnaire where $1=$ strongly disagree, and $5=$ strongly agree. The survey questionnaire was adopted because the data collected permitted statistical analysis which generates results that are easier to interpret (Creswell, 2014). Earlier authors provided the scale items of the variables of the study. The indicator items of credibility were from Erdem and Swait (2004), image from Yoo, Donthu and Lee (2000) and Gil, Andrés and Salinas (2007), satisfaction from He, Li and Harris (2012) and Delgado-Ballester and Munuera-Alemán (2005) and behavioural intentions from Zeithaml et al. (1996), Zhang et al. (2020) and Netemeyer et al. (2004). The research assistants distributed the questionnaires to the customers who were leaving the herbal stores after purchases using a systematic sampling technique. To take part in the study, the customers have to indicate if they have ever bought herbal medicine for consumption. The aim was to obtain accurate perceptions of the customers on brand credibility, behavioural intentions, satisfaction and brand image of the herbal medications distributed in Metropolis. Two hundred and sixty-five questionnaires were distributed, but 208 were used for the analysis due to the respondents' incomplete responses. 


\section{Data Analysis and Results}

The statistical techniques employed to analyse the data were descriptive statistics, exploratory factor analysis (EFA) and covariance-based structural equation modelling (C-SEM), using statistical software known as SPSS Amos 20.

Sample Characteristics: The study's sample characteristics relate to the age, gender, and educational background of the respondents. Descriptive statistics were employed to report the findings of the sample characteristics, which show that most of the participants were male, youth and held secondary education. In the other words, 104 (50.7\%) were male, 81(39.1\%) were between 26 and 35 years, and 74 (36.5\%) had secondary education.

Exploratory Factor Analysis: The EFA was conducted to determine how well the multiple indicators correlate with their stated constructs. For this purpose, 18 indicator items were used for the EFA through the principal axis factoring using the oblimin rotation method. Table 1 below presents the results of the EFA which show that Kaiser-Meyer-Olkin (KMO) Measure of Sampling Adequacy is above .60 (Pallant, 2013), and Bartlett's Test of Sphericity is also significant at $\mathrm{p}<.05$ (Hair, Black, Babin \& Anderson, 2010), which provided support to the EFA. Besides, the EFA through the pattern matrix produced a four-factor model. Factor 1 signifies brand credibility, 2 is customer satisfaction, 3 is behavioural intentions, and 4 is the brand image. A total of 16 indicators were maintained because loadings less than .30 were eliminated (Floyd \& Widaman, 1995). Moreover, all four factors had eigenvalues exceeding 1.0 and predicted $62.43 \%$ of the analysis' total variance. Besides, coefficient alpha was used to examine the reliability of the indicators generated from the EFA to exclude those with low inter-item correlations from the analysis. The findings presented in Table 1 show that the coefficient alpha of all the latent constructs exceeded .70, ranging from .748 to .861, suggesting good internal consistency (Tavakol \& Dennick, 2011).

Table 1: Results of the Exploratory Factor Analysis

\begin{tabular}{|c|c|c|c|c|c|}
\hline \multirow{2}{*}{\multicolumn{2}{|c|}{ Indicators }} & \multicolumn{4}{|l|}{ Factor } \\
\hline & & & 2 & 3 & 4 \\
\hline BC2 & $\mathrm{X}$ delivers what it promises & .793 & & & \\
\hline BC4 & X's product claims are believable & .733 & & & \\
\hline BC3 & $\mathrm{X}$ has the ability to deliver what it promises & .723 & & & \\
\hline BC5 & $\begin{array}{l}\text { Over time, my experiences had led } \mathrm{X} \text { to expect it to } \\
\text { keep its promises. }\end{array}$ & .695 & & & \\
\hline BC1 & $\mathrm{X}$ has a name you can trust & .690 & & & \\
\hline CS2 & I am very pleased with $X$ & & .807 & & \\
\hline CS3 & I am very delighted with $X$ & & .784 & & \\
\hline CS1 & I am completely satisfied with $\mathrm{X}$ & & .696 & & \\
\hline CS4 & I am not very disappointed with X & & .688 & & \\
\hline RPI2 & I intend to keep buying more of $X$ in the future & & & .729 & \\
\hline WTPP1 & $\begin{array}{l}\text { I would be willing to continue to buy more of } X \text { even if } \\
\text { its price increases somewhat }\end{array}$ & & & .705 & \\
\hline RPI1 & $\begin{array}{l}\text { I would consider } \mathrm{X} \text { as my first choice when buying } \\
\text { herbal medicine }\end{array}$ & & & .673 & \\
\hline WOM2 & $\begin{array}{l}\text { I would recommend } \mathrm{X} \text { to someone who asks for my } \\
\text { advice }\end{array}$ & & & .427 & \\
\hline BI3 & I like the image of $\mathrm{X}$ in the marketplace & & & & .753 \\
\hline BI2 & I can quickly recall the symbol or logo of X & & & & .626 \\
\hline BI1 & $\mathrm{X}$ is different from its competing brands & & & & .572 \\
\hline \multicolumn{2}{|c|}{ Cronbach Alpha } & .861 & .812 & .761 & .748 \\
\hline \multicolumn{2}{|c|}{ Eigenvalues } & 5.672 & 2.537 & 1.608 & 1.419 \\
\hline \multirow{2}{*}{\multicolumn{2}{|c|}{$\begin{array}{l}\text { Percentage of Variance Explained } \\
\text { Percentage of Total Variance Explained }=62.426\end{array}$}} & 31.511 & 14.095 & 8.936 & 7.883 \\
\hline & & & & & \\
\hline \multicolumn{6}{|c|}{ KMO $=.835 ;$ Bartlett`s Test of Sphericity: $X 2=1567.481 ; D F=153 ; p=.000$} \\
\hline
\end{tabular}


Structural Equation Modelling: The C-SEM was employed to evaluate the hypotheses formulated in the study. The C-SEM was used because the data collected entails unobserved variables measured by multiple indicators. The C-SEM is also recognised as an efficient and suitable multivariate statistical method for examining a series of separate multiple equations simultaneously. It also offers an overall model fit and estimates measurement errors of the individual indicator items (Hair et al., 2014; Byrne, 2016). The C-SEM analysis was conducted by using a two-stage approach, as recommended by Byrne (2016).

Confirmatory Factor Analysis: The CFA was conducted to validate the findings of the EFA. Indicator items with standardised regression weights of less than .50 were excluded to enhance the convergent validity of the constructs (Hair et al., 2014). Hence, 2 indicators of credibility, 1 of satisfaction and 1 of the behavioural intentions were removed from the analysis. Table 2 reports the CFA outcomes, which reveal that 12 indicators loaded on the four factors, and all the standardised estimates were significant, ranging between .580 and .863 . This result provides a test of construct validity (ibid). The Chi-square test (CMIN $=81.485, \mathrm{df}=$ $48, p=.002$ ) did not validate the model due to its sensitivity to sample size (Byrne, 2016). However, the other fit measures supported the analysis. Goodness-of-Fit Index (GFI) = .940; Adjusted Goodness of Fit (AGFI) = .903; Normed Chi-Square statistic $(\mathrm{CMIN} / \mathrm{DF})=1.698$; Root Mean Residual $(\mathrm{RMR})=.049$; Standardised Root Mean Square Residual (SRMR) = .053; Incremental Fit Index (IFI) = .964; Comparative Fit Index (CFI) = .963; Tucker-Lewis Index $(\mathrm{TLI})=.949$; and Normed Fit Index $(\mathrm{NFI})=.916$. These results display a good model fit (Hu \& Bentler, 1999; Kline, 2015; Hair et al., 2014).

Table 2: Results of the Confirmatory Factor Analysis

\begin{tabular}{lcc}
\hline $\begin{array}{l}\text { Latent Variables and Scale Items } \\
\text { Brand Credibility }\end{array}$ & Standardized Loadings & t-values \\
\hline BC2 & .847 & $-\mathrm{a}$ \\
BC3 & .799 & 11.657 \\
BC4 & .741 & 10.902 \\
Brand Image & & \\
BI3 & .775 & $-\mathrm{a}$ \\
BI2 & .674 & 7.867 \\
BI1 & .673 & 7.866 \\
Customer Satisfaction & & \\
CS1 & .748 & $-\mathrm{a}$ \\
CS2 & .822 & 10.113 \\
CS3 & .772 & 9.907 \\
Behavioural Intentions & & \\
WTPP1 & .580 & $-\mathrm{a}$ \\
RPI2 & .718 & 7.402 \\
RPI1 & .863 & 7.495 \\
\hline
\end{tabular}

Notes: a $=$ path parameter was set to 1 ; therefore, no critical ratio values were estimated; all standardised loadings are significant at $\mathrm{p}=0.001$ level.

Psychometric Measures of Confirmatory Factor Analysis: The psychometric measures analysed in the CFA include composite reliability and construct validity. The convergent validity and the discriminant validity were used to analyse the construct validity (Bagozzi \& Yi, 1988; Hair et al., 2014) and were measured by using Fornell and Lacker (1981) criterion and average variance extracted (Bagozzi \& Yi, 1988) respectively. The analysis in Table 3 reports the outcomes of the latent variables' psychometric properties, which demonstrate that all the AVEs exceeded the suggested value of .50, confirming convergent validity (Bagozzi \& Yi, 1988). Besides, the square roots of the AVEs exceeded the squared inter-factor correlations, supporting discriminant validity (Fornell \& Lacker, 1981). The study, however, established that brand image contributes to enhancing the behavioural intentions of customers through the impact of their satisfaction with brands sold in the TM market in the metropolis. Furthermore, due to biasedness of the coefficient alpha to the number of test items which leads to under-estimation of internal consistency, composite reliability was adopted because it is regarded as a slightly enhanced composite measure of latent variables reliability in the CFA (Hair, Sarstedt, Hopkins \& Kuppelwieser, 2014). Table 3 also exhibits the composite reliability test findings which suggest that all the coefficients were above 0.70 , supporting the latent variables' internal 
consistency. These results show that the latent variables are reliable and valid for the analysis of the path model.

Table 3: Results of Psychometric Measures

\begin{tabular}{lllllll}
\hline Latent Variables & CR & AVEs & BI & CS & BC & BEH \\
\hline Brand Image (BI) & .751 & .503 & $.709^{* *}$ & & & \\
Customer Satisfaction & .821 & .610 & .066 & $.781^{* *}$ & & \\
Brand Credibility (BC) & .839 & .635 & .309 & .062 & $.797^{* *}$ & \\
Behavioural Intentions (BEH) & .769 & .532 & .118 & .164 & .204 & $.729^{* *}$ \\
\hline
\end{tabular}

Notes: $\alpha=$ Cronbach`s alpha; CR = composite reliability; AVEs = Average Variance Extracted; ${ }^{* *}=$ Square root of AVEs; Off-diagonal estimates measure the squared inter-construct correlations.

Structural Model: The path analysis was employed to evaluate the hypothesised relationship between the latent variables in the study. As indicated earlier, brand image and credibility are independent variables, while customer satisfaction is the mediating variable and behavioural intention is the dependent variable. The Chi-square test $(\mathrm{CMIN}=127.021, \mathrm{DF}=49, \mathrm{p}<.001)$ rejected the path model. However, the CMIN $/ \mathrm{DF}=$ 2.592; GFI $=.913 ; \mathrm{IFI}=.916 ; \mathrm{TLI}=.884 ; \mathrm{CFI}=.914 ; \mathrm{RMSEA}=.088$ were satisfactory. The findings of the path model are shown in Table 4, which reveal that credibility is directly related to satisfaction $(\beta=.179, p=.031)$, and behavioural intentions $(\beta=.335, \mathrm{p}=.000)$ at a significance level of $\mathrm{p}<.05$, supporting $H 1$ and $H 2$ respectively. However, the direct relationship between image $(\beta=.122, p=.144)$ and behavioural intentions is not statistically significant, rejecting $H 3$. The findings also indicate that the direct relationship between image $(\beta=.173, \mathrm{p}=.049)$, and satisfaction is significant at $\mathrm{p}<.05$, confirming $H 4$. Finally, the satisfaction $(\beta=$ $.303, \mathrm{p}=.000$ ) is directly related to behavioural intentions at $\mathrm{p}<.05$, supporting $H 5$.

Table 4: Results of the Path Model

\begin{tabular}{lllll}
\hline Hypotheses & Structural Relations & $\begin{array}{l}\text { Standardized } \\
\text { Estimate }\end{array}$ & C.R. & p-value \\
\hline H1 & Customer Satisfaction <-----Brand Credibility & .179 & 2.161 & .031 \\
H2 & Behavioural Intentions <--- Brand Credibility & .335 & 3.800 & .000 \\
H3 & Behavioural Intentions <--- Brand Image & .122 & 1.461 & .144 \\
H4 & Customer Satisfaction <-----Brand Image & .173 & 1.966 & .049 \\
H5 & Behavioural Intentions <--- Customer Satisfaction & .303 & 3.380 & .000 \\
\hline
\end{tabular}

Mediation Testing: This paper also sought to test the mediational role of customer satisfaction in the relationship between credibility and behavioural intentions (H6), and image and behavioural intentions (H7). Following Baron and Kenny's (1986) guide for evaluating mediation which entails; (1) regressing the mediator on the independent variable; (2) the dependent variable on the independent variable; and (3) the dependent variable on both the independent variable and the mediator. Consequently, the mediational relationships were examined by using a bootstrap re-sampling method. The findings indicate that the direct effect of credibility $(\beta=.335, \mathrm{p}=.001)$ on behavioural intentions is significant at $\mathrm{p}<0.05$. The analysis further shows that the indirect effect of credibility $(\beta=.054, \mathrm{p}=.067)$ on behavioural intentions is not statistically significant at $\mathrm{p}<.05$. These outcomes indicate that there is no mediational relationship between credibility and behavioural intentions. More so, the findings show that the direct effect of brand image $(\beta=.122, p=$ .346) on behavioural intentions is not significant at $p<0.05$. However, the indirect effect of image $(\beta=.053, p$ $=.027$ ) on behavioural intentions is significant at $\mathrm{p}<0.05$. These findings prove that satisfaction acts as a full mediator in the path between image and behavioural intentions.

\section{Discussion}

The research aimed to evaluate the impact of brand credibility, image and satisfaction on customers' behavioural intentions in the TM market in the Cape Coast metropolis. More importantly, the study sought to determine the intervening role of satisfaction in the effect of credibility and image on customers' behavioural intentions in the TM market in the Cape Coast metropolis. The findings point out that credibility directly influences customer satisfaction in the TM market in the metropolis. This outcome is in line with previous 
authors (Othman et al., 2017; Ameri \& Behnam, 2014) who found that credible brands enhance customers` brand satisfaction. A credible brand is perceived to be reliable and therefore continuously deliver value to the target customers which ultimately, creates greater customer satisfaction in the market. Furthermore, the research revealed that customer satisfaction is significantly influenced by the brand image in the TM market. This outcome is similar to past research (Izzudin \& Novandarii, 2018; Yulianti \& Tung, 2013), which suggest that delighted customers have positive perceptions about brands they purchase from the market. These findings show that brand credibility and image are essential ingredients for building customer satisfaction in the TM market in the Cape Coast metropolis.

The study`s results further point out that brand credibility significantly enhances the TM market customers` behavioural intentions. This outcome is similar to the prior research (Ali et al., 2013; Ryu et al., 2012), which revealed that credibility directly impacts the behavioural intentions to engage in repurchase intentions and the desire to pay a premium price. Moreover, the research established that satisfaction contributes to strengthening the customers' behavioural intentions in the TM market in Cape Coast. This outcome concurs with previous studies (Rambocas et al., 2018; Cronin et al., 2000), which show that satisfaction elicits favourable customers' intentions to future re-purchase and pay a premium price. These outcomes demonstrate that credibility and customer satisfaction are the key sources of behavioural intentions in the TM market in the metropolis. The study found that the direct path between the brand image and behavioural intentions was not significant. This outcome supports earlier research (Ali et al., 2013), which indicated the relationship between a Malaysian resort hotel's brand image and tourists' behavioural intentions was not significant. However, this outcome differs from a prior study (Lee et al., 2010), reporting that the overall image of the brands directly impacts the customers' behavioural intentions in green hotels in the United States of America. This outcome suggests that customer ' brand satisfaction plays a critical role in enriching the image of the brands which eventually, reinforces the customers` behavioural intentions in the TM market in Cape Coast.

\section{Conclusion and Recommendations}

Conclusion: The main objective of the research was to analyze the influence of credibility, image, and satisfaction on customers' behavioral intentions in the TM market in Cape Coast. Specifically, the study sought to evaluate customer satisfaction's meditational role in the relationship between brand credibility, image and customers' behavioral intentions in the TM market. The research confirmed that brand credibility and image are essential sources of customer satisfaction in the TM market. The study further established that credibility and satisfaction are crucial indicators of the customers' behavioral intentions in the TM market. The study showed that brand image has no significant direct effect on the customers' behavioral intentions in the TM market. However, brand image positively influenced customers` behavioral intentions via customer satisfaction in the TM market. Thus, the study established that satisfaction plays a perfect role in the relationship between brand image and customers' behavioral intentions in the TM market. In this regard, the research concludes that brand image, credibility and satisfaction are critical factors that enhance the customers` behavioral intentions in the TM market in the Cape Coast metropolis.

Recommendations: Guided by the findings of the research, the recommendations made are spelt out below, which may contribute to enhancing the strategic branding decisions of the practitioners in the TM market. The research indicates that brand credibility and image have a direct impact on customer satisfaction in the TM market in the Cape Coast metropolis. Consequently, TM practitioners should develop their brand`s credibility and image to enhance customer satisfaction in the market in Cape Coast. The study also reported that brand credibility and customer satisfaction significantly enhance customers' behavioural intentions in the TM market. As a result, the TM practitioners should design programs to create and track their brand's credibility and customers' satisfaction to strengthen the behavioural intentions of the customers in the TM market in the metropolis. The study results also show that the relationship between brand image and customers' behavioural intentions was not significant. For this reason, the TM practitioners should endeavour to build a strong image of their brands, which may strengthen the behavioural intentions of the customers in the market in the metropolis. The findings also indicate that brand image positively influences the customers' behavioural intentions through the mediated impact of the customers' brand satisfaction. Therefore, recognising the vital role of customer satisfaction in the relationship between the brand image and 
behavioural intentions, the TM practitioners should develop brands that will delight their customers to strengthen their brand's image and ultimately, the customers' behavioural intentions in the TM market in the metropolis.

Limitations and Direction of Future Research: This paper has strong literature and methodology, yet it has some limitations that need to be resolved if a similar future study is conducted. The TM market includes instore and online market environment, but data were gathered from the in-store market environment. Future research should consider both online and in-store environment. The study also looked at the plant medicines produced and packaged by Ghanaian firms. Hence, complementary and alternative medicines (CAM) that are alien to Ghanaian culture were not considered in the study. Future studies should involve both CAM and herbal medicines produced by Ghanaians. Quantitative methods were adopted in this research, and it is, therefore, proposed that future research looks at mixed methods to improve its generalisability. Furthermore, the study considered only finished herbal medicines, and hence, future research should consider raw herbal and herbal preparations.

\section{References}

Aaker, D. A. (1991). Managing Brand Equity: Capitalising on the Value of Brand Name. New York: The Free Press.

Ali, F., Omar, R. \& Amin, M. (2013). An Examination of the Relationships between Physical Environment, Perceived Value, Image and Behavioural Intentions: A SEM Approach towards Malaysian Resort Hotels. Journal of Hotel and Tourism Management, 27(2), 9-26.

Ameri, H. S. \& Behnam, M. (2014). The Effect of Brand Credibility on Consumers` Perceptions about Brands and their Purchasing Behaviours in Sports Goods. Sport Science, 7(2), 50-57.

Bagozzi, R. P. \& Yi, Y. (1988). On the Evaluating Structural Equation Models. Journal of Academy of Marketing Research, 16(1), 074-094.

Baron, R. M. \& Kenny, D. A. (1986). The Moderator-Mediator Variable Distinction in Social Psychology Research: Conceptual, Strategic, and Statistical Considerations. Journal of Personality and Social Psychology, 51(6), 1173-1182.

Byrne, B. M. (2016). Structural Equation Modelling with AMOS: Basic Concepts, Applications and Programming, ( $3^{\text {rd }}$ ed.), New York: Taylor \& Francis.

Buil, I., Martinez, E. \& de Chernatony, L. (2013). The Influence of Brand Equity on Consumer Responses. Journal of Consumer Marketing, 30 (1), 62-74.

Creswell, J. W. (2014). Research Design: Qualitative, Quantitative, and Mixed Methods Approaches, (4th Ed.). California: SAGE Publications

Cronin, J. J. Jr., Brady, M. K. \& Hutt, G. T. M. (2000). Assessing the Effects of Quality, Value, and Customer Satisfaction on Consumer Behavioral Intentions in Service Environments. Journal of Retailing, 76(2), 193-218.

Delgado-Ballester, E. \& Munuera-Alemán, J. L. (2005). Does Brand Trust Matter to Brand Equity? Journal of Product \& Brand Management, 14(3), 187-196.

Erdem, T. \& Swait, J. (1998). Brand Equity as a Signaling Phenomenon. Journal of Consumer Research Psychology, 7(2), 131-157.

Erdem, T. \& Swait, J. (2004). Brand Credibility, Brand Consideration, and Brand Choice. Journal of Consumer Research, 13, 191-198.

Essegbey, G. O., Awuni, S., Essegbey, I. T., Akuffobea, M. \& Mica, B. (2014). Country Study on Innovations, Intellectual Property and Informal Economy: Traditional Medicines in Ghana, (13 ${ }^{\text {th }}$ ed.), Geneva: World International Property Organization.

Ferrell, O. C. \& Hartline, M. C. (2011). Marketing Strategy, (5 ${ }^{\text {th }}$ Ed.). USA: Cengage Learning.

Floyd, F. J. \& Widaman, K. F. (1995). Factor Analysis in the Development and Refinement of Clinical Assessment Instrument. Psychological Assessment, 7(3), 286-299.

Fornell, C. \& Larcker, D. F. (1981). Evaluating Structural Equation Models with Unobservable Variables and Measurement Error. Journal of Marketing Research, 18(1), 39-50.

Gil, R. B., Andrés, E. F. \& Martinez, E. S. (2007). Family as a Source of Customer-Based Brand Equity. Journal of Product \& Brand Management, 16(3), 188-199. 
Hair, J. H. Jr., Black, W. C., Babin, B. J. \& Anderson, R. E. (2014). Multivariate Data Analysis, (7th ed.), England: Pearson Education.

Hair, J. H. Jr., Sarstedt, M., Hopkins, L. \& Kuppelwieser, V. G. (2014). Partial Least Squares Structural Equation Modelling (PLS-SEM): An Emerging Tool in Business Research. European Business Review, 26(2), 106121.

He, H., Li, Y. \& Harris, L. (2012). Social Identity Perspective on Brand Loyalty. Journal of Business Research, 65, 648-657.

Hu, L. \& Bentler, P. M. (1999). Cut-off Criteria for Fit Indexes in Covariance Structure Analysis: Conventional Criteria versus New Alternatives. Structural Equation Modelling: Multidisciplinary Journal, 6(1), 1- 55.

Izzudin, M. S. \& Novandarii, W. (2018). The Effect of Perceived Quality, Brand Image on Customer Satisfaction and Brand Awareness towards Repurchase Intentions. Journal of Research in Management, 1(3), 3243.

Keller, K. L. (1993). Conceptualisation, Measuring and Managing Customer-Based Brand Equity. Journal of Marketing, 57(1), 1-22.

Keller, K. L. (2013). Strategic Brand Management: Building Measuring, and Managing Brand Equity, Global Edition, ( $4^{\text {th }}$ ed.), England: Pearson Education.

Kline, R. B. (2015). Principles and Practice of Structural Equation Modelling, (2 ${ }^{\text {nd }}$ ed.), New York: Guilford Press.

Kotler, P. \& Keller, K. L. (2012). Marketing Management, (14 $4^{\text {th }}$ Ed.). New Jersey: Pearson Education, Inc.

Krejcie, R. V. \& Morgan, D. V. (1970). Determining Sample Size for Research Activities. Education and Psychological Measurement, 30, 607-610.

Lee, J. S., Hsu, L. J. H., Han, H. \& Kim, Y. (2010). Understanding How Consumers View Green Hotels: How a Hotel`s Green Image Can Influence Behavioural Intentions. Journal of Sustainable Tourism, 18(7), 901-914.

Lovelock, C. \& Wirtz, J. C. (2016). Services Marketing: People, Technology and Strategy, (8 ${ }^{\text {th }}$ ed.), USA: Pearson Education.

Malhotra, N. K., Nunan, D. \& Birks, D. F. (2017). Marketing Research: An Applied Approach, (5 ${ }^{\text {th }}$ Ed.). United Kingdom: Pearson Education.

Miles, M. B., Huberman, A. M. \& Saldaña, J. (2014). Qualitative Data Analysis: A Methods Sourcebook, (3 ${ }^{\text {rd }}$ Ed.). USA: SAGE Publication.

Netemeyer, R. G., Krishna, B., Pullig, C., Wang, G., Yagci, M., Dean, D., Ricks, J. \& Wirth, F. (2004). Developing and Validating Measures of Facets of Customer-based Brand Equity. Journal of Business Research, 57, 209-224.

Othman, M., Kamarohim, N. \& Nizam, F. M. (2017). Brand Credibility, Perceived Quality and Perceived Value. International Journal of Economics \& Management, 11(S5), 765-775.

Pallant, J. (2013). SPSS Survival Manual: A Step by Step Guide to Data Analysis using IBM SPSS (5 $5^{\text {th }}$ ed.), New York: McGraw-Hill Education.

Rambocas, M., Kirpalani, V. M. \& Simms, E. (2018). Brand Equity and Customer Behavioural Intentions: A Mediated Moderated Model. International Journal of Bank Marketing, 36(1), 19-40.

Ryu, K., Han, H. \& Kim, T. H. (2012). The Relationships among Overall Quick-causal Restaurant Image, Perceived Value, Customer Satisfaction, and Behavioural Intentions. International Journal of Hospitality Management, 27, 459-469.

Saha, G. C. \& Theingi, T. (2009). Service Quality, Satisfaction, and Behavioural Intentions: A Study of Low-Cost Airline Carriers in Thailand. Managing Service Quality, 19(3), 350-372.

Tavakol, M. \& Dennick, R. (2011). Making Sense of Cronbach's Alpha. International Journal of Medical Education, 2, 53-55.

UNDP. (2007). The Ghana Human Development Report: Towards a More Inclusive Society, Ghana (http://www.hrd.undp.org/sites/default/files/nhdr_ghana.pdf: Accessed July 7, 2020).

WHO. (2007). WHO guidelines for assessing the quality of herbal medicines with reference to contaminants and residues. Geneva, Switzerland: WHO Press.

WHO. (2008). Traditional Medicine. Fact Sheet No. 134

(http://www.who.int/medicines/areas/traditional/definitions/en/pdf: Accessed June 4, 2020)

WHO. (2011). Traditional Medicines, Global Situation, Issues, and Challenges. The World Medicines Situation.

Yoo, B., Donthu, N. \& Lee, S. (2000). An Examination of Selected Marketing Mix Elements and Brand Equity. Journal of the Academy of Marketing Science, 28(2), 195-211. 
Yulianti, I. \& Tung, W. (2013). The Relationship among Brand Experience, Brand Image and Customer Satisfaction of Facebook Users in Indonesia. World Applied Sciences Journal, 28, 100-113.

Zeithaml, V. A., Bitner, M. J. \& Gremler, D. D. (2018). Services Marketing: Integrating Customer Focus Across the Firm, (7th Ed.). New York: McGraw-Hill.

Zeithaml, V. A., Berry, L. L. \& Parasuraman, A. (1996). The Behavioural Consequences of Service Quality. Journal of Marketing, 60, 31-46.

Zhang, S., Peng, Y. P., Peng, Y., Zhang, Y., Ren, G. \& Chen, C. C. (2020). Expressive Brand Relationship, Brand Love, and Brand Loyalty for Tablet PC: Building Sustainable Brand. Frontiers in Psychology, 11, 1-10. 